\title{
THE EFFECT OF DIFFERENT PHOSPHORUS DOSES ON AGRONOMIC AND QUALITY CHARACTERISTICS OF CORIANDER (CORIANDRUM SATIVUM L.)
}

\author{
IZGI, M. N. \\ Kiziltepe Technical Vocational School of Higher Education, Mardin Artuklu University, \\ Mardin, Turkey \\ (e-mail: necatizgi@ hotmail.com; phone: +90-532-655-30-83; ORCID: 0000-0003-1657-1169)
}

(Received 25 $5^{\text {th }}$ Jul 2020; accepted $22^{\text {nd }}$ Oct 2020)

\begin{abstract}
In a two-year study, under the environmental conditions of the plains of Mardin province in Turkey, the effects of different doses of phosphorus $\left(0,30,60,90,120 \mathrm{~kg} \mathrm{ha}^{-1}\right)$ on the yield and quality characteristics of the coriander (Coriandrum sativum L.) were examined. Plant characteristics such as plant height, number of branches, number of umbels, thousand seed weight and seed yield were examined, besides quality characteristics such as essential oil rate and composition. The essential oil was isolated with a Clevenger apparatus from mature fruits. Essential oil components were determined with Gas chromatography-mass spectrometry (GC-MS). The results revealed that phosphorus doses affect the plant characteristics of coriander including plant height, number of branches, number of umbels and thousand fruit weight with positive significance. Fruit yield was not affected significantly. Phosphorus doses had a significant positive effect on essential oil rate. Increasing phosphorus doses affected rates of $\alpha$-pinene, geranyl acetate and camphor positively. However, Linalool and $\gamma$-terpinene were not affected by phosphorus doses significantly. The application of $120 \mathrm{~kg}$ phosphorus per hectare, which had the highest essential oil rate in both years, can be recommended in coriander farming.
\end{abstract}

Keywords: Coriandrum sativum L., essential oil, linalool, phosphorus doses, yield

\section{Introduction}

Coriander (Coriandrum sativum L.) is a medicinal and aromatic plant belonging to the Apiaceae family and widely used as a spice (Diederichsen, 1996; Maroufi et al., 2010; Chawla and Thakur, 2013). The fruit is divided into two varieties according to its diameter. The small-fruited var. microcarpum is in the diameter range of $1.5-3 \mathrm{~mm}$ while the large-fruited varieties var. vulgare Alef. var. sativum are in the diameter range of 3-5 mm. Each mericarp has 5 wavy ridges. The secretory canal is on the side of the mericarps facing each other and there are two canals (Tanker et al., 1998). In coriander, there is an inverse correlation between fruit size and essential oil rate. As the seed size increases, essential oil rate decreases (Telci et al., 2006a). Large-fruited coriander is generally grown in tropical and subtropical climatic zones and contains low level of essential oil (0.1-0.4\%) (Telci et al., 2006b).

Coriander, which is used in many spice compositions and widely used in Indian Curry, is one of the spices with a great reputation all over the world and has a significant place in international trade. According to 2014 data of the Food and Agriculture Organization (FAO), total production amount of Anise, Fennel and Coriander plants is 970.000 tons in the world.

Turkey produced totally 42 tons of coriander in 2016 and earned 221.269 US dollar income from the export (Keykubat, 2016). According to the 2018 data of TURKSTAT, considering the foreign trade numbers in Turkey between 2007 and 2017, import was continuously higher than export on the basis of US dollar expect for 2012 and 2013 and only 29 tons of coriander were obtained in 2018 (Turkish Statistical Institute, 2019). 
The parts of the plant such as fruit, leaf and flower have antimicrobial, antioxidant, antidiabetic, anxiolytic, anticonvulsant, antidepressant, antimutagenic, anti-inflammatory, anti-dyslipidemic, antihypertensive and diuretic effects (Burdock and Carabin, 2009; Sahib et al., 2013).

Coriander fruits contain essential oil and fatty oil. The essential oil rates of coriander fruits vary between $0.03 \%$ and $2.6 \%$. The main component of essential oil was reported to be linalool (Gokduman and Telci, 2018; Momin et al., 2012; Izgi et al., 2017; Telci et al., 2006a, b).

Phosphorus is a significant plant nutrient for plant growth. Phosphorus enables potassium uptake by plants and conducts energy transfer in plants, plays a significant role in providing cell division by entering the structure of nucleoproteins. In addition, phosphorus in the soil has great benefits for plant root development. As the root development increases depending on the amount of phosphorus, the contact surface of the root develops in the soil, thus increasing the utilization of the necessary nutrient content of the plants (Marschner, 2011). In agricultural areas of Turkey, lack of available phosphorus and increasingly excessive phosphorus fertilization is still among the most significant problems of plant nutrition and fertilization (Matar et al., 1992).

This study was conducted with an aim to determine the effect of different phosphorus applications on yield and plant characteristics, essential oil rate and their main components in coriander (Coriandrum sativum L.), a significant medicinal and spice plant.

\section{Materials and methods}

Coriander (Coriandrum sativum L.) is a spice plant that belongs to the Apiaceae family and its fruits are used. As the experiment material, Gamze, which is a registered cultivar in Turkey, was used. This study was carried out for two years under the plain conditions (Gollu Village) of Mardin Province in Turkey during the 2014-2015 and 2015-2016 vegetation periods.

The plain conditions of Mardin province where the study was conducted are hot and dry in summers, rainy and warm in winters. When the climate data belonging to past periods and the years when the experiment was conducted were examined, it was seen that the temperature and humidity values were similar in both years; however, when the precipitation values were examined, differences were observed in December, January, February, March and April values and precipitation values were lower especially in the second year (Table 1).

Table 1. Some meteorological values for long years (2004-2016) and 2014-2015-2016 growing periods in Mardin province. (Sources: Turkish State Meteorological Service)

\begin{tabular}{c|c|c|c|c|c|c|c|c|c}
\hline \multirow{2}{*}{ Months } & \multicolumn{3}{|c|}{ Rainfall (mm) } & \multicolumn{3}{c|}{ Temperature $\left({ }^{\circ}\right.$ C) } & \multicolumn{3}{c}{ Relative humidity (\%) } \\
\cline { 2 - 9 } & Long years & $\mathbf{2 0 1 4 - 2 0 1 5}$ & $\mathbf{2 0 1 5 - 2 0 1 6}$ & Long years & $\mathbf{2 0 1 4 - 2 0 1 5}$ & $\mathbf{2 0 1 5}-2016$ & Long years & $\mathbf{2 0 1 4 - 2 0 1 5}$ & $\mathbf{2 0 1 5 - 2 0 1 6}$ \\
\hline November & 33.3 & 76.8 & 46.0 & 14 & 12.7 & 12.4 & 51.6 & 53.1 & 50.3 \\
December & 54.8 & 100.4 & 34.8 & 9.1 & 5.8 & 7.3 & 54.3 & 72.2 & 51.7 \\
January & 42.8 & 8.3 & 73.2 & 7.1 & 6.8 & 5.2 & 60.3 & 66.6 & 75.2 \\
February & 47.6 & 76.0 & 35.8 & 8.8 & 8.2 & 11.0 & 60.0 & 68.7 & 65.8 \\
March & 34.2 & 89.9 & 59.9 & 13.1 & 10.8 & 12.0 & 52.0 & 60.3 & 59.0 \\
April & 37.7 & 25.4 & 9.3 & 17.5 & 14.0 & 17.4 & 49.3 & 53.0 & 41.3 \\
May & 17.3 & 11.1 & 12.3 & 23.7 & 21.2 & 21.0 & 37.0 & 37.3 & 42.0 \\
June & 2.4 & 0.2 & 0.5 & 30.5 & 26.9 & 29.1 & 22.8 & 29.0 & 28.2 \\
July & 0.4 & 0.0 & 0.0 & 34.1 & 33.1 & 32.5 & 22.0 & 19.6 & 22.4 \\
\hline
\end{tabular}


As seen in Table 2, the soil has a clay-loam structure and is poor in terms of organic matter $(1.18 \%)$. Lime content is very high $(36.65 \%)$, slightly alkaline $(\mathrm{pH}=8.05)$ and has no salinity problem (0.010\%). Phosphorus favorable for intake in soil (31.5 kg ha-1) is low and rich in terms of potassium $\left(104.16 \mathrm{mg} \mathrm{kg}^{-1}\right)$. Soil structure is sufficient in terms of iron $\left(7.9050 \mathrm{mg} \mathrm{kg}^{-1}\right)$, copper $\left(33.000 \mathrm{mg} \mathrm{ha}^{-1}\right)$ and magnesium $\left(292.6 \mathrm{mg} \mathrm{kg}^{-1}\right)$ but insufficient in terms of manganese $\left(3.390 \mathrm{mg} \mathrm{kg}^{-1}\right)$ and zinc $\left(0.8112 \mathrm{mg} \mathrm{kg}^{-1}\right)$ (Table 2).

Table 2. Soil properties of the experimental area

\begin{tabular}{|c|c|c|c|}
\hline Analyses (0-30 cm) & Limit values & Analysis results & Analysis method \\
\hline Phosphorus (P) & $<3$ Trace & $29.2 \mathrm{mg} \mathrm{kg}^{-1}$ & TS ISO 11263 \\
\hline Potassium (K) & $>30$ Sufficient & $111.44 \mathrm{mg} \mathrm{kg}^{-1}$ & TS 8341 \\
\hline Lime $(\%)$ & $>25$ Excessive calcic & $33.39 \%$ & TS EN ISO 10693 \\
\hline $\mathrm{pH}$ & 7.5-8.5 Light alkaline & $8.08 \%$ & TS ISO 10390 \\
\hline Organic substance $(\%)$ & 1-2 Little & $1.15 \%$ & TS8336 \\
\hline Salinity $(\%)$ & $<2$ Salt-free & $0.010 \%$ & TS ISO 11265 \\
\hline Mangan (Mn) & 4-14 Insufficient & $5.150 \mathrm{mg} \mathrm{kg}^{-1}$ & Tuzuner, 1990 \\
\hline Iron $(\mathrm{Fe})$ & $>4.5$ Sufficient & $11.121 \mathrm{mg} \mathrm{kg}^{-1}$ & Tuzuner, 1990 \\
\hline Copper $(\mathrm{Cu})$ & $>0.2$ Sufficient & $33.000 \mathrm{mg} \mathrm{kg}^{-1}$ & Tuzuner, 1990 \\
\hline Zinc (Zn) & $>8$ Excessive & $11.314 \mathrm{mg} \mathrm{kg}^{-1}$ & Tuzuner, 1990 \\
\hline Calcium (Ca), & 1150-3500 Sufficient & $1216.6 \mathrm{mg} \mathrm{kg}^{-1}$ & Tuzuner, 1990 \\
\hline Magnesium (Mg) & 160-480 Sufficient & $250.6 \mathrm{mg} \mathrm{kg}^{-1}$ & Tuzuner, 1990 \\
\hline Sodium $(\mathrm{Na})$ & -- & $64.68 \mathrm{mg} \mathrm{kg}^{-1}$ & Tuzuner, 1990 \\
\hline Organic carbon & -- & $0.67 \%$ & TS8336 \\
\hline Carbon/nitrogen $(\mathrm{C} / \mathrm{N})$ & -- & $0.55 \%$ & Calculation method \\
\hline Structure & $\begin{array}{c}\text { Sand } 39.2 \% \\
\text { Clay } 32.7 \% \\
\text { Silt } 28.0 \%\end{array}$ & CL (Clayey loamy) & Tuzuner, 1990 \\
\hline
\end{tabular}

Soil analyses were made in MARTEST Analysis Laboratories Ind.

The experiment was set up according to the Randomized Blocks Experiment Design with three replications. In the phosphorus fertilization, normal superphosphate (NSP) fertilizer was used. The phosphorus fertilizer was applied to the plots by mixing with the soil, with plantation, in 5 different doses $\left(0,30,60,90,120 \mathrm{~kg} \mathrm{ha}^{-1}\right)$. The plot area has a total area of 4.5 $\mathrm{m}^{2}$ with 5 rows on each plot with $3 \mathrm{~m}$ length, $1.5 \mathrm{~m}$ width and $30 \mathrm{~cm}$ planting distance. In the plantation, $1 \mathrm{~m}$ distance between plots and $2 \mathrm{~m}$ between blocks were arranged. $10 \mathrm{~kg} \mathrm{ha}^{-1}$ seed rate was used in the study. Sowings were performed manually on the 15th October 2014 in the first year and on the 16th October 2015 in the second year. After the sowing, weeding was performed three times and irrigation was made as needed by controlling the soil humidity in the summer months. On the 23rd June the harvest was performed manually; calculations were made on the current area by removing $25 \mathrm{~cm}$ as edge effect from the row tops and one row on the sides.

\section{Essential oil analysis}

Volumetric method was used for the extraction and quantitation of essential oils in matter coriander fruits and for distillation; fruits were ground and subjected to 
distillation for $2.5 \mathrm{~h}$ with Clevenger device (Clevenger, 1928). The essential oils obtained were stored in a refrigerator at $+4{ }^{\circ} \mathrm{C}$ until the analysis.

Essential oil component analysis was performed in GC/MS-QP2020 analysis device. The device conditions were given in Table 3.

Table 3. GC/MS conditions

\begin{tabular}{c|c}
\hline System & GC/MS-QP2020 \\
\hline GC capillary column & For essential oil analysis: Rtx-2330 RESTEK $(60 \mathrm{~m} \times 0.25 \mathrm{~mm} \times 0.2 \mu \mathrm{m})$ \\
\hline Injection mode & Split \\
\hline Pressure & For essential oil analysis: $80 \mathrm{kPa}$ \\
\hline Split rate & For essential oil component analysis: 25 \\
\hline GC oven initial temperature & $\begin{array}{c}\text { For essential oil component analysis: Initial } 40^{\circ} \mathrm{C} 2 \text { min holding period } \\
4{ }^{\circ} \mathrm{C} \mathrm{m^{-1 }} \text { until } 240^{\circ} \mathrm{C} \text { final temperature } 240{ }^{\circ} \mathrm{C} 3 \text { min holding period }\end{array}$ \\
\hline Injection block temperature & For essential oil component analysis: $240^{\circ} \mathrm{C}$ \\
\hline FID temperature & $250{ }^{\circ} \mathrm{C}$ \\
\hline Injection volume & $1 \mu 1$ \\
\hline
\end{tabular}

\section{Data analysis}

Agronomic characters were analyzed by using the JMP 5.0.1 statistical program (SAS Institute Inc., 2002), and the differences between means of phosphorus doses were compared using Student's t-test at the 0.05 probability level (Gosset, 1908).

The analysis of essential oil was applied using the IBM SPSS Statistics for Windows (IBM Corp., 2017). The significance of year differences of essential oil between fruit samples was tested by analysis of variance (ANOVA) and represented by critical value from F-test $(\mathrm{F})$ and statistical significance (p). Essential oil means and major components of essential oil with significant variation were compared by using least significant difference (LSD) test. Year difference significances were compared by T-test.

\section{Results and discussion}

\section{Agronomic characteristics and yield}

\section{Plant height $(\mathrm{cm})$}

Effect of phosphorus doses on mean data of plant height was found statistically significant $(\mathrm{p}<0.05)$. Year differences were insignificant. Plant height varied between 36.7 and $51.5 \mathrm{~cm}$ in the first year and 39.3 and $55.0 \mathrm{~cm}$ in the second year. According to mean data of doses, statistically $(\mathrm{p}<0.05)$ the highest value $(53.3 \mathrm{~cm})$ was obtained at $90 \mathrm{~kg} \mathrm{ha}^{-1}$ phosphorus application and the lowest value $(38.0 \mathrm{~cm})$ was measured in the control group. It can be stated that the increasing phosphorus doses affected plant height positively (Table 4).

In the study of NP fertilization, Khalid (2012) found significant $(\mathrm{p}<0.05)$ effect of fertilizer (NP) on plant height of coriander and value between 42.6 and $70.7 \mathrm{~cm}$. He stated that plant height increased by increasing phosphorus doses. Javiya et al. (2017) found significant relation between phosphorus doses and plant height and found values between 51.86 and $60.47 \mathrm{~cm}$. The highest value is obtained at $60 \mathrm{~kg} \mathrm{ha}^{-1}$ phosphorus application. Farahani et al. (2008) found the effect of phosphorus doses on plant height insignificant. 
Table 4. Some agronomical characteristics of different phosphorus dose applications in coriander (Coriandrum sativum L.)

\begin{tabular}{|c|c|c|c|c|c|c|c|c|c|c|c|c|c|c|c|}
\hline \multirow{2}{*}{$\begin{array}{c}\text { Phosphorus } \\
\text { doses } \\
\left(\mathrm{kg} \mathrm{ha}^{-1}\right)\end{array}$} & \multicolumn{3}{|c|}{ Plant height (cm) } & \multicolumn{3}{|c|}{$\begin{array}{l}\text { Number of branches } \\
\text { (branches plant }^{-1} \text { ) }\end{array}$} & \multicolumn{3}{|c|}{$\begin{array}{l}\text { Number of umbels } \\
\left.\text { (umbels plant }^{-1}\right)\end{array}$} & \multicolumn{3}{|c|}{$\begin{array}{l}1000 \text { fruit weight } \\
\text { (gr) }\end{array}$} & \multicolumn{3}{|c|}{$\begin{array}{l}\text { Fruit yield } \\
\left(\mathbf{k g ~ h a}^{-1)}\right.\end{array}$} \\
\hline & 2015 & 2016 & Mean & 2015 & 2016 & Mean & 2015 & 2016 & Mean & 2015 & 2016 & Mean & 2015 & 2016 & Mean \\
\hline 0 & 36.7 & 39.3 & $38.0 \mathrm{c}$ & 4.0 & 4.9 & $4.4 \mathrm{bc}$ & 9.5 & 11.2 & $10.3 b$ & 12.8 & 12.9 & $12.9 \mathrm{a}$ & 1546 & 2618 & 2082 \\
\hline 30 & 47.8 & 51.8 & $48.2 \mathrm{~b}$ & 3.8 & 5.0 & $4.4 \mathrm{c}$ & 11.0 & 12.5 & $11.8 \mathrm{~b}$ & 12.3 & 12.4 & $12.3 \mathrm{~b}$ & 1957 & 2511 & 2234 \\
\hline 60 & 50.1 & 48.6 & 51.4ab & 3.5 & 4.7 & $4.1 \mathrm{c}$ & 11.6 & 13.0 & $12.3 \mathrm{~b}$ & 12.9 & 12.7 & $12.8 \mathrm{a}$ & 1965 & 2599 & 2282 \\
\hline 90 & 51.5 & 52.6 & 53.3a & 4.5 & 6.0 & $5.3 \mathrm{bc}$ & 14.2 & 17.2 & $15.7 \mathrm{a}$ & 12.3 & 12.2 & $12.3 \mathrm{~b}$ & 203.2 & 2490 & 2261 \\
\hline 120 & 48.4 & 55.0 & 50.1ab & 5.9 & 6.8 & $6.4 \mathrm{a}$ & 15.7 & 16.2 & $16.0 \mathrm{a}$ & 12.4 & 12.3 & $12.4 \mathrm{~b}$ & 1740 & 2107 & 1923 \\
\hline Mean & 46.9 & 49.5 & & $4.3 \mathrm{~b}$ & $5.5 \mathrm{a}$ & & $12.4 \mathrm{~b}$ & $14.0 \mathrm{a}$ & & $12.6 \mathrm{a}$ & $12.5 \mathrm{~b}$ & & $1848 b$ & $2465 a$ & \\
\hline
\end{tabular}

The difference between the mean indicated in the same letter is not significant $(\mathrm{P}<0.05)$

\section{Number of branches (branches plant ${ }^{-1}$ )}

Regarding number of branches, differences between mean data of doses and differences between mean data of years were statistically significant $(\mathrm{p}<0.05)$. It was detected as 4.3 in the first year and 5.5 in the second year. According to mean data of doses, the highest branch number ( 6.4 branches plant $\left.{ }^{-1}\right)$ was obtained at $120 \mathrm{~kg} \mathrm{ha}^{-1}$ phosphorus application) while the lowest branch number (4.1 branches) was obtained at $60 \mathrm{~kg} \mathrm{ha}^{-1}$ phosphorus application. The results of the study show that the increasing phosphorus doses had a positive significant effect on the number of branches. In the second year, high rainfall values encouraged vegetative growth of the plant, thus increasing the number of branches (Table 4).

Regarding the number of branches, Khalid (2012) stated that there was a positive significant relation between phosphorus doses and number of branches. He obtained the highest value (7.8 plant $\left.^{-1}\right)$ at $56.3 \mathrm{~kg} \mathrm{ha}^{-1}$ phosphorus application. Javiya et al. (2017) found significant positive effect of phosphorus doses on number of branches and values were between 16.95 and 22.22 branches per plant. They measured the highest number of branches at $60 \mathrm{~kg} \mathrm{ha}^{-1}$ phosphorus application. In their study of water stress and phosphorus doses effect on coriander, Hani et al. (2015) determined that the number of branches increased significantly by increasing phosphorus doses and values without water stress were between 3.79 and 4.71 . They obtained the highest value at $24 \mathrm{~kg} \mathrm{ha}^{-1}$ phosphorus application. It could be said that phosphorus doses increase number of branches in coriander plant significantly. It can be said that differences of obtained values may be related to the applied cultivation techniques and the effect of ecological and genotypical factors.

\section{Number of umbels (umbels plant ${ }^{-1}$ )}

The differences between the years and between the doses were found to be significant $(\mathrm{p}<0.05)$ in terms of the umbel number. It was detected that there were 12.4 umbels per plant in 2015 while there were 14 umbels in 2016. Considering the mean data of the doses, the highest number of umbels ( 16 umbels plant $\left.^{-1}\right)$ was detected in the $120 \mathrm{~kg} \mathrm{ha}^{-1}$ phosphorus application while the lowest umbel (10.3 umbels) was detected in the control group. In the new studies to be conducted on branch number in plant, 120 $\mathrm{kg} \mathrm{ha}^{-1}$ and higher phosphorus doses per hectare should be experimented. Furthermore, the differences observed between the years especially in terms of precipitation values affected the high umbel numbers for two years (Table 4). 
Hani et al. (2015), Javiya et al. (2017) and Khalid (2012) claimed that number of umbels in coriander plant was significantly affected from different doses. Respectively, Hani et al. (2015), Javiya et al. (2017) and Khalid (2012) obtained values varying between 5.63-6.97; 8.97-12.42 and 13.9-24.7 umbels per plant. The highest number of umbels was measured at $56.3 \mathrm{~kg} \mathrm{ha}^{-1}$ application in Khalid (2012), $60 \mathrm{~kg} \mathrm{ha}^{-1}$ in Javiya et al. (2017) and $24 \mathrm{~kg} \mathrm{ha}^{-1}$ in Hani et al. (2015). Studies on the effect of phosphorus doses on number of umbels prove that increasing doses provide enhancement in number of umbels.

\section{Thousand fruit weight $(g)$}

In terms of the thousand fruit weight, the differences between the doses used in the study were found to be statistically significant $(\mathrm{p}<0.05)$ according to both experimental doses and average of the years. The thousand fruit weight was detected as $12.6 \mathrm{~g}$ in the first year and $12.5 \mathrm{~g}$ in the second year. In the average of the years, the highest value $(12.9 \mathrm{~g})$ was obtained from the control group while the lowest value $(12.3 \mathrm{~g})$ was obtained from $30 \mathrm{~kg} \mathrm{ha}^{-1}$ and $90 \mathrm{~kg} \mathrm{ha}^{-1}$ phosphorus application (Table 4).

In their research of row spacing Kizil and Ipek (2004) found values between $12.51 \mathrm{~g}$ and $13.90 \mathrm{~g}$ with $30 \mathrm{~kg} \mathrm{ha}^{-1}$ phosphorus application. Javiya et al. (2017) and Jan et al. (2011) found significant effect of phosphorus doses on thousand fruit weight and values between $13.12 \mathrm{~g}$ and $13.99 \mathrm{~g}$ and $8.59 \mathrm{~g}$ and $9.83 \mathrm{~g}$ respectively. Javiya et al. (2017) obtained the highest value at $60 \mathrm{~kg} \mathrm{ha}^{-1}$ phosphorus application and Jan et al. (2011) at $45 \mathrm{~kg} \mathrm{ha}^{-1}$ phosphorus application. Sannappanavar et al. (2019) and Kan (2007) found effect of phosphorus on thousand seed weight as insignificant and they measured values between $9.45 \mathrm{~g}$ and $10.60 \mathrm{~g}$ and $9.60 \mathrm{~g}$ and $10.14 \mathrm{~g}$ respectively. According to results obtained in the study and in other studies, it is revealed that, increasing phosphorus doses has positive effect on thousand fruit weight.

\section{Fruit yield $\left(\mathrm{kg} \mathrm{ha}^{-1}\right)$}

In the fruit yield, the difference between the years was significant but not significant between the mean data of the doses. The yield was obtained as $1848 \mathrm{~kg} \mathrm{ha}$ ${ }^{1}$ in the first year and $2465 \mathrm{~kg} \mathrm{ha}^{-1}$ in the second year. In the mean data of doses, the highest value $\left(2282 \mathrm{~kg} \mathrm{ha}^{-1}\right)$ was obtained from the $60 \mathrm{~kg} \mathrm{ha}^{-1}$ phosphorus application while the lowest value $\left(1923 \mathrm{~kg} \mathrm{ha}^{-1}\right)$ was obtained from the $120 \mathrm{~kg} \mathrm{ha}^{-1}$ phosphorus application (Table 4). It is thought that the differences between the fruit yield according to the years are related to the higher precipitation values especially in the second year.

According to fruit yield of coriander Hani et al. (2015), Jan et al. (2011), Javiya et al. (2017) and Sannappanavar et al. (2019) found significant effect of phosphorus doses on coriander and they reported positive relation. Respectively they found, values between 2774-3669 kg; 894-1023 kg; 1219-1422 kg and 511-665 kg per hectare. They measured the highest values at the highest phosphorus applications. However, Kan (2007) found the effect of phosphorus doses as insignificant. While literature proves positive effect of phosphorus doses on fruit yield, result in this paper is not significant. Fruit yield shows significant changes depending on variety, climate, genetic and environmental factors, seed time and agricultural practices (Yamanol, 1996; Toncer and Tansi, 1997; Toncer et al., 1998; Gok, 2011). 


\section{Essential oil contents (\%)}

Difference between mean data of year was not statistically significant for essential oil content (Table 5). First year mean value was $0.20 \%$ and second year it was $0.21 \%$. Regarding to mean data of dose differences, the highest value $(0.23 \%)$ was obtained at $120 \mathrm{~kg} \mathrm{ha}^{-1}$ phosphorus dose and the lowest value was obtained in the control group. Doses and interaction factors were statistically significant $(\mathrm{p}<0.01)$ but year factor was not significant. Essential oil increases according to increasing phosphorus doses; While the 1st year increased regularly, the 2nd year became irregular (Table 6). If we evaluate according to the year averages; As there is an increase in essential oil rates in parallel with increasing phosphorus doses, $120 \mathrm{~kg}$ of phosphorus application may be recommended to hectare.

Table 5. Variation of mean, standard deviation and $F$ data in coriander essential oil content and components cultivated in two different years

\begin{tabular}{c|c|c|c|c}
\hline \multirow{2}{*}{ Components } & \multirow{2}{*}{$\mathbf{R T}$} & $\mathbf{1}^{\text {st }}$ Year & $\mathbf{2}^{\text {nd }}$ Year & \multirow{2}{*}{$\boldsymbol{F}$ Values } \\
\cline { 3 - 4 } & & Mean $+\mathbf{S D}$ & Mean + SD & \\
\hline$\alpha$-pinene & 6.803 & $7.93 \pm 1.64 \mathrm{a}$ & $6.43 \pm 0.70 \mathrm{~b}$ & $10.71^{* *}$ \\
Camphene & 8.115 & $0.88 \pm 0.16 \mathrm{a}$ & $0.75 \pm 0.08 \mathrm{~b}$ & $7.99^{* *}$ \\
$\beta$-pinene & 9.502 & $0.72 \pm 0.11 \mathrm{a}$ & $0.63 \pm 0.06 \mathrm{~b}$ & $8.36^{* *}$ \\
Sabinene & 10.003 & $0.53 \pm 0.08 \mathrm{a}$ & $0.47 \pm 0.05 \mathrm{~b}$ & $5.96^{*}$ \\
Myrcene & 11.554 & $1.09 \pm 0.15 \mathrm{a}$ & $0.91 \pm 0.10 \mathrm{~b}$ & $14.17^{* *}$ \\
Limonene & 12.788 & $2.16 \pm 0.29 \mathrm{a}$ & $1.86 \pm 0.22 \mathrm{~b}$ & $10.79^{* *}$ \\
$\gamma$-terpinene & 14.565 & $7.86 \pm 0.93 \mathrm{a}$ & $7.00 \pm 0.54 \mathrm{~b}$ & $9.58^{* *}$ \\
p-cymene & 15.501 & $4.52 \pm 0.59$ & $4.00 \pm 0.81$ & $4.07^{\text {ns }}$ \\
Terpinolene & 15.878 & $0.40 \pm 0.06 \mathrm{a}$ & $0.34 \pm 0.04 \mathrm{~b}$ & $8.27^{* *}$ \\
Camphor & 24.285 & $4.09 \pm 0.71$ & $4.12 \pm 0.78$ & $0.02^{\text {ns }}$ \\
Linalool & 25.254 & $59.98 \pm 6.86$ & $63.00 \pm 4.96$ & $1.91^{\text {ns }}$ \\
Terpinen-4-ol & 26.956 & $0.33 \pm 0.12$ & $0.32 \pm 0.14$ & $0.02^{\text {ns }}$ \\
$\alpha$-Terpineol & 29.850 & $0.34 \pm 0.09$ & $0.36 \pm 0.10$ & $0.39^{\text {ns }}$ \\
Isoborneol & 30.027 & $0.10 \pm 0.09$ & $0.13 \pm 0.09$ & $1.01^{\text {ns }}$ \\
Geranyl acetate & 31.601 & $5.05 \pm 1.67$ & $5.21 \pm 1.32$ & $0.08^{\text {ns }}$ \\
L-Citronellol & 31.753 & $0.13 \pm 0.08 \mathrm{~b}$ & $0.20 \pm 0.06 \mathrm{a}$ & $5.91^{*}$ \\
Geraniol & 34.147 & $2.42 \pm 0.76$ & $2.82 \pm 0.71$ & $2.25^{\text {ns }}$ \\
Dodec-2(E)-enal & 34.701 & $0.12 \pm 0.11$ & $0.14 \pm 0.10$ & $0.22^{\text {ns }}$ \\
Essential oil & & $0.20 \pm 0.03$ & $0.21 \pm 0.03$ & $2.49^{\text {ns }}$ \\
\hline
\end{tabular}

$* \mathrm{p}<0.05 ; * * \mathrm{p}<0.01 ;$ ns: not significant

According to the European Pharmacopeia, the coriander fruit should have an essential oil concentration that is higher than $0.03 \%$ (Ullah and Honermeier, 2013). Kizil and Ipek (2004) obtained value between 0.28 and 0.32 by application of $60 \mathrm{~kg} \mathrm{ha}^{-1}$ nitrogen and $30 \mathrm{~kg} \mathrm{ha}^{-1}$ phosphorus. In their study of cultivar and location, Izgi et al. (2017) measured $0.50 \%$ of essential oil in Mardin plain conditions with Gamze cultivar. Regarding different phosphorus doses; Khalid, 2012, 2015; and Hani et al., 2015 claimed that essential oil rate increase with increasing phosphorus doses and they found values as $0.47-0.53 ; 0.20-0.40$ and $0.20-0.60$ respectively. However, Kan (2007) did not find the effect of phosphorus doses significant. Results showed that essential oil rate 
was affected by increasing phosphorus doses. Differences between increase rates and total ratios of essential oil in fruit can be caused from different ecological conditions, different cultivars or various cultural application during cultivation process.

Table 6. Variation in essential oil content and major components of essential oil of coriander (Coriandrum sativum L.) according to Year $(Y)$ and phosphorus doses $(P)$

\begin{tabular}{|c|c|c|c|c|c|c|c|}
\hline & \multirow{2}{*}{ Years } & \multicolumn{5}{|c|}{ Phosphorus doses $\left(\mathrm{kg} \mathrm{ha}^{-1}\right)$} & \multirow{2}{*}{ Mean $^{Y}$} \\
\hline & & $\mathbf{0}$ & 30 & 60 & 90 & 120 & \\
\hline \multirow{3}{*}{ Essential oil } & $\mathbf{1}^{\text {st }}$ & 0.16 & 0.19 & 0.20 & 0.20 & 0.23 & $0.20 \mathrm{a}$ \\
\hline & $2^{\text {nd }}$ & 0.22 & 0.23 & 0.17 & 0.20 & 0.23 & $0.21 \mathrm{a}$ \\
\hline & Mean $^{\mathrm{P}}$ & $0.19 b$ & $0.21 \mathrm{ab}$ & $0.19 b$ & $0.20 \mathrm{~b}$ & $0.23 a$ & \\
\hline Factors & & $\mathbf{Y}^{\mathrm{NS}}$ & & $\mathbf{P} * *$ & & $\mathbf{Y x P} * *$ & \\
\hline \multirow{3}{*}{ Linalool } & $1^{\text {st }}$ & 58.10 & 58.68 & 60.40 & 66.06 & 56.67 & 59.98a \\
\hline & $2^{\text {nd }}$ & 67.66 & 63.80 & 59.92 & 64.10 & 59.51 & $63.00 \mathrm{a}$ \\
\hline & Mean $^{\mathrm{P}}$ & 62.88 & 61.24 & 60.16 & 65.08 & 58.09 & \\
\hline Factors & & $\mathbf{Y}^{\mathrm{NS}}$ & & $\mathbf{P}^{\mathrm{NS}}$ & & $\mathbf{Y x P} P^{N S}$ & \\
\hline \multirow{3}{*}{$\gamma$-terpinene } & $1^{\text {st }}$ & 7.73 & 7.89 & 8.24 & 7.07 & 8.37 & $7.86 a$ \\
\hline & $2^{\text {nd }}$ & 7.61 & 6.71 & 6.89 & 6.84 & 6.93 & $7.00 \mathrm{~b}$ \\
\hline & Mean $^{P}$ & 7.67 & 7.30 & 7.57 & 6.96 & 7.65 & \\
\hline Factors & & $\mathbf{Y}^{* * *}$ & & $\mathbf{P}^{\mathrm{NS}}$ & & $\mathbf{Y x P}^{\mathrm{NS}}$ & \\
\hline \multirow{3}{*}{ Geranyl acetate } & $1^{\text {st }}$ & 7.49 & 4.68 & 5.64 & 2.82 & 4.64 & $5.05 a$ \\
\hline & $2^{\text {nd }}$ & 3.28 & 4.56 & 6.18 & 5.28 & 6.75 & $5.21 \mathrm{a}$ \\
\hline & Mean $^{P}$ & 5.39a & $4.62 \mathrm{~b}$ & $5.91 \mathrm{a}$ & $4.05 \mathrm{c}$ & $5.70 \mathrm{a}$ & \\
\hline Factors & & $\mathbf{Y}^{\mathrm{NS}}$ & & $\mathbf{P} * *$ & & $\mathbf{Y x P * *}$ & \\
\hline \multirow{3}{*}{$\alpha$-pinene } & $1^{\text {st }}$ & 5.39 & 8.31 & 7.66 & 9.22 & 9.08 & $7.93 a$ \\
\hline & $2^{\text {nd }}$ & 6.83 & 7.20 & 6.48 & 5.97 & 5.65 & $6.43 b$ \\
\hline & Mean $^{P}$ & $6.11 \mathrm{c}$ & $7.76 a$ & $7.07 b$ & 7.60ab & 7.37ab & \\
\hline Factors & & $\mathbf{Y * *}$ & & $\mathbf{P} * *$ & & YxP** & \\
\hline \multirow{3}{*}{ Camphor } & $1^{\text {st }}$ & 4.94 & 3.71 & 4.23 & 3.31 & 4.24 & $4.09 a$ \\
\hline & $2^{\text {nd }}$ & 3.29 & 3.91 & 4.88 & 3.53 & 4.99 & $4.12 \mathrm{a}$ \\
\hline & Mean $^{P}$ & $4.12 \mathrm{~b}$ & $3.81 \mathrm{~b}$ & $4.56 \mathrm{a}$ & $3.42 \mathrm{c}$ & $4.62 a$ & \\
\hline Factors & & $\mathbf{Y}^{\mathrm{NS}}$ & & $\mathbf{P} * *$ & & $\mathbf{Y x P} \mathbf{P}^{* * *}$ & \\
\hline
\end{tabular}

$* \mathrm{p}<0.05 ; * * \mathrm{p}<0.01 ;$ NS: not significant

\section{Essential oil components}

In the study where the effect of different doses of phosphorus in the coriander grown under the plain conditions of Mardin province on essential oil components, 18 components were detected in total. Linalool, $\gamma$-terpinene, $\alpha$-pinene, geranyl acetate and camphor were determined in coriander as the major components (Table 6). For linalool, main factors of year, phosphorus doses and interaction were found insignificant statistically (Table 5 and 6). First and second years were respectively $59.98 \%$ and $63 \%$, and year differences were not statistically significant (Table 5). Regarding mean data of doses, the highest value was observed at $90 \mathrm{~kg} \mathrm{ha}^{-1}$ phosphorus application. However, differences between doses were not statistically significant. Regarding $\gamma$-terpinene, year factor was statistically significant $(\mathrm{p}<0.01)$. Phosphorus doses and interaction were not 
statistically significant. Statistically $(\mathrm{p}<0.05)$ the highest value $(7.86 \%)$ was obtained in the first year. While the highest mean value $(7.67 \%)$ of doses was observed at the control group, differences were not significant. Main factor of year was not statistically significant for geranyl acetate. However, factor of doses and interaction were significant $(\mathrm{p}<0.01)$. In the second year, higher value $(5.21 \%)$ was obtained but year differences were not statistically significant. According to mean data of doses, the highest value $(5.91 \%)$ was obtained at $60 \mathrm{~kg} \mathrm{ha}^{-1}$ phosphorus application and the lowest value $(4.05 \%)$ was obtained at $90 \mathrm{~kg} \mathrm{ha}^{-1}$ phosphorus application. Regarding main factors of $\alpha$-pinene, year, phosphorus doses and interaction were significant $(\mathrm{p}<0.01)$ statistically. For year differences, significantly $(\mathrm{p}<0.05)$ higher value $(7.93 \%)$ was obtained in the first year. According to differences of doses, top value (7.76\%) was measured at $30 \mathrm{~kg} \mathrm{ha}^{-1}$ phosphorus application, the highest value $(6.11 \%)$ was obtained in the control group. Main factors of phosphorus doses and interaction were found significant $(\mathrm{p}<0.01)$ statistically, but main factor of year was not significant. Higher value was measured in the second year as $4.12 \%$, however difference was not significant. Differences between mean data of doses were tested and found significant $(\mathrm{p}<0.05)$. Maximum value (4.62\%) was observed at $120 \mathrm{~kg} \mathrm{ha}^{-1}$ phosphorus application, minimum value $(3.42 \%)$ was obtained at $90 \mathrm{~kg} \mathrm{ha}^{-1}$ phosphorus doses (Table 6).

Rao et al. (1983) reported that the different doses of phosphorus $\left(0,30,60 \mathrm{~kg} \mathrm{ha}^{-1}\right)$ did not affect the linalool rate varying between 57.9 and $63.3 \%$ in coriander. In the study of essential oil content of coriander applying boron fertilization Beyzi and Gunes (2017) determined linalool, camphor and $\gamma$-terpinene as the main components by $50 \mathrm{~kg} \mathrm{ha}^{-1}$ phosphorus and nitrogen application with Gamze cultivar. The highest rates that they detected are between $83.81-91.40 \%, 2.21-3.67 \%$ and $0.88-3.76 \%$, respectively. In their study of cultivar and location, Izgi et al. (2017) determined linalool, neryl acetate, $\alpha$-pinene and $\gamma$-terpinene as the major components of essential oil in coriander by $50 \mathrm{~kg} \mathrm{ha}^{-1}$ phosphorus and nitrogen application with Gamze cultivar in Mardin plain conditions and they measured values of $82.2 \%, 3.6 \%, 0.3 \%$ and $4.2 \%$, respectively. According to effect of phosphorus doses, Khalid (2015) obtained 15 components of essential oil and determined linalool (75.5\%-75.7\%), limonene (6.8\%-7.0\%) and camphor (3.7-3.9) as major components. He did not find significant effect of doses on major components, but he found significant differences of doses for sabinene and $\alpha-$ pinene. In the study about water regime and phosphorus fertilization effect on essential oil of coriander, Hani et al. (2015) found 19 components and linalool (35.13\%-65.58\%), nerol (3.52\%-22.36\%) and $\alpha$-terpineol $(7.17 \%-16.68 \%)$ as major components. They found the effect of phosphorus doses on major components of essential oil in coriander as significant. According to these results, effect of phosphorus doses on essential oil composition of coriander differs to cultivar, climatic conditions, water regime or cultural applications.

\section{Conclusions}

Aim of this research was to determine the effect of phosphorus fertilization on coriander to fruit yield and quality. Experiments were carried out in plain conditions of Mardin province in Turkey. The effect of different phosphorus doses applied to the plant on fruit yield was statistically insignificant. The effect of different phosphorus doses applied to the plant on the essential oil ratio of the coriander fruit was statistically significant. The highest essential oil rate $(0.23 \%)$ was obtained from $120 \mathrm{~kg}$ phosphorus 
application per hectare. Different phosphorus doses applied to the plant had no statistical effect on linalool ratio. Since it contributes to the increase of essential oil ratio; $120 \mathrm{~kg}$ of phosphorus application can be recommended per hectare.

Acknowledgments. This work was supported by the Mardin Artuklu University BAP Coordinator, it forms part of the project numbered MAÜ-BAP-16-KMYO-16 and titled "The Effect of Different Nitrogen and Phosphorus Doses in Coriander and Black Cumin on Yield and Quality".

\section{REFERENCES}

[1] Beyzi, E., Gunes, A. (2017): The effects of boron application on essential oil components of coriander plant (Coriandrum sativum L.). - J. Agricultural Faculty of Gaziosmanpasa University. 34(1): 146-152. DOI: 10.13002/jafag4205.

[2] Burdock, G. A., Carabin, I. G. (2009): Safety assessment of coriander (Coriandrum sativum L.) essential oil as a food ingredient. - Food and Chemical Toxicology 47(1). DOI: 10.1016/j.fct.2008.11.006.

[3] Chawla, S., Thakur, M. (2013): Coriandrum sativum: a promising functional and medicinal food. medicinal plants. - International J. Phytomedicines and Related Industries 5(2). DOI: 10.5958/j.0975-6892.5.2.009.

[4] Clevenger, J. F. (1928): Apparatus for the determination of volatile oil. - J. The American Pharmaceutical Assc. 17(4): 345-349. DOI: 10.1002/jps.3080170407.

[5] Diederichsen, A. (1996): Coriander (Coriandrum sativum L.); Promoting the Conservation and Use of Underutilized and Neglected Crops: 3. - Institute of Plant Genetics and Crop Plant Research, Gartensleben, pp. 1-82.

[6] Farahani, H. A., Lebaschi, M. H., Hamidi, A. (2008): Effects of arbuscular mycorrhizal fungi, phosphorus and water stress on quantity and quality characteristics of coriander. Advances in Natural and Applied Sciences 2(2): 55-59.

[7] Food and Agriculture Organization of United Nations (FAO) (2014): www.fao.org.

[8] Gok, N. (2011): Determining of yield and quality characteristics of coriander (Coriandrum sativum L.) varieties cultivated on different dates. - Master Thesis, Van Yuzuncu Yil University.

[9] Gokduman, G. A., Telci, I. (2018): Determination of yield and quality characteristics of some coriander (Coriandrum sativum L.) genotypes in Isparta conditions. - Suleyman Demirel University J. Natural and Applied Sciences 22(3):1165-1168. DOI: 10.19113/sdufenbed.470129.

[10] Gosset, W. S (1908): Student: In the Application of the 'Law of Error' to the Work of the Brewery: 3-6.

[11] Hani, M. M., Hussein, S.-A. A. H. A., Mursy, M. H., Ngezimana, W., Mudau, F. N. (2015): Yield and essential oil response in coriander to water stress and phosphorus fertilizer application. - J. Essential Oil-Bearing Plants 18(1): 82-92. DOI: 10.1080/0972060X.2014.974080.

[12] IBM Corp (2017): IBM SPSS Statistics for Windows. - IBM Corp., Armonk, NY.

[13] Izgi, M. N., Telci, I., Elmastas, M. (2017): Variation in essential oil composition of coriander (Coriandrum sativum L.) varieties cultivated in two different ecologies. - J. Essential Oil Research 29(6): 494-498. DOI: 10.1080/10412905.2017.1363090.

[14] Jan, I., Sajid, M., Shah, A. H., Rab, A., Khan, N. H., Fazal-i-Wahid, Rahman, A., Alam, R., Alam, H. (2011): Response of seed yield of coriander to phosphorus and row spacing. - Sarhad J. Agriculture 27(4): 549-552.

[15] Javiya, P. P., Solanki, J. N., Kaneria, S. C., Rupareliya, V. V. (2017): Response of coriander (Coriandrum sativum L.) to nitrogen and phosphorus in South Saurashtra condition. - Int. J. Pure App. Biosci 5(4): 860-66. DOI: 10.18782/2320-7051.5183. 
[16] Kan, Y. (2007): The effect of organic and inorganic fertilizer on yield and essential oil of coriander (Coriandrum sativum L.) growing In Konya ecological conditions. - Selcuk J. Agriculture and Food Sciences 21(42): 36-42.

[17] Keykubat, B (2016): Tibbi Aromatik Bitkiler ve İyi Yasam. - Commodity Exchange, Izmir.

[18] Khalid, K. A. (2012): Effect of phosphorous fertilization on anise, coriander and sweet fennel plants growing under arid region conditions. - Medicinal and Aromatic Plant Science and Biotechnology 6(1): 127-31.

[19] Khalid, K. A. (2015): Effect of macro and micronutrients on essential oil of coriander fruits. - JMES 6(8): (2060)-2065.

[20] Kizil, S., Ipek, A. (2004): The effects of different row spacing on yield, yield components and essential oil content of some coriander (Coriandrum sativum L.) lines. - J. Agricultural Science 10(3): 237-44.

[21] Maroufi, K., Farahani, H. A., Darvishi, H. H. (2010): Importance of coriander (Coriandrum sativum L.) between the medicinal and aromatic plants: - Advances in Environmental Biology 4(3): 433-436.

[22] Marschner, H. (2011): Marschner's Mineral Nutrition of Higher Plants. 3rd Ed. Academic Press, Cambridge, MA. https://doi.org/10.1016/C2009-0-63043-9.

[23] Matar, A., Torrent, J., Ryan, J. (1992): Soil and Fertilizer Phosphorus and Crop Responses in the Dryland Mediterranean Zone. - In: Stewart, B. A. (ed.) Advances in Soil Science. Springer, New York, pp. 81-146. DOI: 10.1007/978-1-4612-2844-8_3.

[24] Momin, A. H., Acharya, S. S., Amit, G. V. (2012): Coriandrum sativum - review of advances in phytopharmacology. - International J. Pharmaceutical Sciences and Research. DOI: 10.13040/IJPSR.0975-8232.3(5).1233-1239.

[25] Rao, E. V. S. P., Singh, M., Narayana, M. R., Rao, R. S. G., Rao, B. R. R. (1983): fertilizer studies in coriander (Coriandrum sativum L.). - The J. Agricultural Science 100(1): 251-52. DOI: 10.1017/S0021859600032706.

[26] Sahib, N. G., Anwar, F., Gilani, A., Hamid, A. A., Saari, N., Alkharfy, K. M. (2013): Coriander (Coriandrum sativum L.): a potential source of high value components for functional foods and nutraceuticals - a review. - Phytotherapy Research 27(10): 14391456.

[27] Sannappanavar, S., Rao, G. G. E., Vasundhara, M. (2019): Performance of coriander (Coriandrum sativum L.) to different sources of organic phosphorus and PSB on growth and seed yield. - International J. Current Microbiology and Applied Sciences 8(8): 258489. DOI: $10.20546 / \mathrm{ijcmas} .2019 .808 .300$.

[28] SAS Institute Inc (2002): JMP ${ }^{\circledR}$. - SAS Institute Inc., Cary, NC.

[29] Sriti, J., Talou, T., Wannes, W. A., Cerny, M., Marzouk, B. (2009): Essential oil, fatty acid and sterol composition of Tunisian coriander fruit different parts. $-\mathrm{J}$. The Science of Food and Agriculture 89(10): 1659-64. DOI: 10.1002/jsfa.3637.

[30] Tanker, N., Koyuncu, M., Coskun, M. (1998): Pharmaceutical Botany. - Ankara University Department of Pharmacy Publications, Ankara.

[31] Telci, I., Bayram, E., Avci, B. (2006a): Changes in yields, essential oil and linalool contents of Coriandrum sativum varieties (Var. Vulgare Alef. and Var. Microcarpum DC.) harvested at different development stages. - European J. Horticultural Science 71(6): 267.

[32] Telci, I., Toncer, O. G., Sahbaz, N. (2006b): Yield, essential oil content and composition of Coriandrum sativum varieties (Var. Vulgare Alef and Var. Microcarpum DC.) grown in two different locations. - J. Essential Oil Research 18(2): 189-93. DOI: 10.1080/10412905.2006.9699063.

[33] Toncer, O., Tansi, S. (1997): Effect of different sowing frequency on yield and essential oil rate in coriander (Coriandrum sativum L.). - Cukurova University J. The Faculty of Agriculture 181: 155-62. 
[34] Toncer, O., Tansi, S., Kizil, S. (1998): The effect of different sowing time on essential oil of coriander in Gap Region. - J. AARI 8(2): 101-5. DOI: 10.18615/anadolu.89959.

[35] Turkish Statistical Institute (2019): TURKSTAT. - Turkish Statistical Institute, Ankara.

[36] Tuzuner, A. (1990): Toprak ve Su Analiz Laboratuvarları El Kitabı. - T.C. Tarım ve Köy İşleri Bakanlığ 1 , Köy Hizmetleri Genel Müdürlüğü, Ankara.

[37] Ullah, H., Honermeier, B. (2013): Fruit yield, essential oil concentration and composition of three anise cultivars (Pimpinella anisum L.) in relation to sowing date, sowing rate and locations. - Industrial Crops and Products 42: 489-99. DOI: 10.1016/j.indcrop.2012.06.011.

[38] Yamanol, A. (1996): The effect of agronomic and technological specialities of different sowing time and seeding rate of culture coriander (Coriandrum sativum L.). - Master Thesis, Ege University. 